\title{
Thomas Mann'ın Büyülü Dağ Adlı Yapıtının Modernizm Açısından Bir Yorumu
}

\section{An Interpretation of Thomas Mann's Magical Mountain in Terms of Modernism}

\author{
Nermin Urganc1 ${ }^{1}$ (D)
}

'Dr. Öğrencisi, Dokuz Eylül Üniversitesi, Sosyal Bilimler Enstitüsü, Felsefe Anabilim Dalı, İzmir, Türkiye

\section{ORCID: N.U. 0000-0002-7253-009X}

Sorumlu yazar/Corresponding author: Nermin Urgancl,

Dokuz Eylül Üniversitesi, Sosyal Bilimler Enstitüsü, Felsefe Anabilim Dalı, Doktora Programı Öğrencisi, İzmir, Türkiye

E-mail/E-posta: myilmaz@uludag.edu.tr

Başvuru/Submitted: 04.03.2019 Revizyon Talebi/Revision Requested: 11.03.2019

Son Revizyon/Last Revision Received: 14.03.2019

Kabul/Accepted: 21.03.2019

\section{Atıf/Citation:}

Urganci, Nermin. “Thomas Mann'ın Büyülü Dağ Adlı Yapıtının Modernizm Açısından Bir Yorumu." Felsefe Arkivi 50 (2019): 79-96. https://doi.org/10.26650/arcp2019-589797

\section{ÖZET}

Thomas Mann (1875-1955), 20. Yüzyıl edebiyatına büyük yön vermiş ve kendisinden de oldukça söz ettiren bir yazar olmuştur. Romanlarının yazarı olmasının dışında karşıtların ustası olarak da tanınmaktadır. Özellikle Buddenbrooks (1901), Venedik'te Ölüm (1912), Büyülü Dağ (1924) adlı yapıtları dünya edebiyatında yazıldığı günden bugüne değin okurlarında aynı tutkuyu yaratmaya devam etmektedir. Bu yapıtlar kimi zaman edebiyatın, psikanalizin konusu olurken kimi zamanda felsefede adından oldukça söz ettirmiştir. Özellikle felsefi açıdan Büyülü Dağ adlı yapıtı incelemek, araştırmaya başlama nedenlerimiz arasında yer almaktadır. İncelememiz boyunca modernist özellikleri sergilemenin yanında, yapıtın çağa ayna tutan yönlerini de ortaya koyacağız. Büyülü Dağ, 19. Yüzyılda hızla yayılmış ve çaresi bulunamayan ama araştırılmaya devam eden verem hastalığından mustarip kişilerin sağlıklarına tekrar kavuşabilmek için gönderilen bir sanatoryumda geçmektedir. Temiz hava, iyi beslenme, zengin bir diyet, hafif egzersiz vaat eden tüberküloz sanatoryumları için yüksek dağlara sahip İsviçre seçilmiştir. Davos kasabasındaki hastaneler, zengin hastaların lekelerini gidermeye çalışırken bir yandan da onları olabildiğince disiplinli bir yaşama zorlamışlardır. Lekeli insanların sanatoryuma gelişi, yeryüzüne bir daha dönmek istememeleri araştırmamızın başlıkları arasında yer almaktadır. Bizim için asıl ilginç olan şey ise yeryüzü ve kasabanın büyülü dağları arasında geçen olay dizileri olmuştur. Dünyaya ait olan bu yerlerin nasıl oluyor da insanlar tarafından farklı algılanıyor oluşu romanın anlatımı boyunca göz önünde tutacağımız şey olacaktır.

Anahtar Kelimeler: Modernizm, leke, yeryüzü, zaman, hız, yaşam

\section{ABSTRACT}

Thomas Mann (1875-1955), was a leading figure in the 20th century and is writer who has been widely mentioned in world litetarure. He is known not only as the writer of milestone novels but also as the master of oppositions. The Buddenbrook's Family (1901), The Death in Venice (1912), and The Magıc Mountain (1924) in particular are inspiring the same emotions in the readers of today as the day they were written. While these masterpieces have been the subject of literature research and psychoanalysis, they have also been of interest in the realm of philosophy. In 
particular, from the perspective of philosophy, The Magic Mountain, was the main concern of this study. This study will indicate both the modern aspects of the story as well as try to show how this work was a mirror for its time. The story takes place in a sanatorium where people who suffering from tuberculosis are sent to recover. This is an illness without remedy in its time and which was widespread through the 19th century. Switzerland, with its lofty mountains, was chosen as a location for tuberculosis senatoriums which offered fresh air, good nutrition, and light exercise. While the hospitals of Davos village tried to treat the patients'lung spots, they also forced them to follow a life of dicipline. The fact that the "spotted" people went to the senatorium, with no intention of going back to their previous life is the main concern of this study. The most interesting fact here is the chain of events that connected earth to the mystical mountains of this town. The main issue will be the question of why people perceived this earthly place in such a different way.

Keywords: Modernism, spot, earth surface, time, speed, life 
Thomas Mann için sıradan bir insan ama yazgısına bireyüstü anlamlar katan Hans Castorp, kuzenini sadece üç haftalık ziyaret etmek için, Hamburg'dan yola çıkıp İsviçre'nin kuzeyinde bulunan Davos-Platz kasabasına doğru yolculuğu başlar. Her modern roman ve kahramanı gibi bizim kahramanımızda romanın sayfaları açıldığında kendisini bir an da trende yolculuk yaparken bulur. Düzlükte mühendislik okumuş olan Hans, ziyaretinden sonra işini yapmak için devam edeceğini sanır, oysa yaşadığı olaylar onu hiçte istemediği şeyleri yapmaya zorlayacaktır. Yolculuğu sırasında düzlükten farklı olan bir şeyle karşılaştı: Zaman. Trene bir hafta önce binmesine rağmen sanki birkaç saat önce yoluculuğu başlamış gibi hissetti. "Saatler geçtikçe mekân ve zamanın oluşturduklarına çok benzeyen ama bazı açılardan onları da aşan değişimlere neden oluyordu." Trenin düzlükten gittikçe uzaklaştığını fark ettiğinde istasyonda bir anda ciğerlerindeki leke tedavisi için burada kalan kuzeni Joachim’i görür oldu. Modern iki insan gibi birbirlerinin boyunlarına atlamak yerine sadece "sen" hitabını yeterli gördüler. "Selamlaşma biraz soğuk ve mesafeli insanların yapısına uygun olarak pek abartılı olmadı." ${ }^{2}$ Bin altı yüz metre yükseklikte olan Davos kasabasında zaman, düzlükte olandan çok daha hızlı akıyor ve insanlar fikirlerini hızla değiştirebiliyordu. Anlaşıldığı gibi burada her şey çok hızlı oluyordu, ölümler, hastalıklar, beslenmeler, sevgiler. Tek yavaş olan şey Hans'ın karşılaşacağı sevgisi olacaktır. Hans Castorp, koridordan 34 numaralı odaya doğru giderken, düzlükten farklı bir şeyle daha karşılaştı. Öksürük sesine benzeyen ama ondan çok daha farklı bir ses duydu. Yaşamla sıkı sıkıyla olan bu delikanlı, ilk kez yaşamdan kopuk sese yöneldi. "Bugüne dek duyduğu öksürükler yaşam dolu kusursuz öksürüklerdi ve onlarla karşılaştırıldığında, bu yaşamdan ve sevgiden yoksun ses, doğal bir öksürük tutmasından çok, çözülmekte olan organik bir maddenin bulamacından çıkan güçsüz ama ürkütücü bir fokurdamayı andırıyordu."3 Tüberkülozla mücadele eden bu lekeli insanlar, Hans için sevgiden, yaşamdan, tutkudan kopmuş halde hasta yataklarında ölümü bekliyorlardı. Alın yazısı aklına geldikçe durgunlaşan kuzeni Joachim'in tek isteği bir an önce iyileşip düzlükte bir kahraman gibi askerlerle omuz omuza olmaktı. Oysa buraya bir kez gelindi mi bir daha gitmek neredeyse imkânsızlaşıyordu. Hatta sanatoryumun başhekimi Behrens, Hans ile ilk kez karşılaştığında sağlıklı bir insanın buraya seyahat amaçlı geldiğine inanamadı. Hastalığının ciddiyetini her firsatta saklamaya çalışan Hans, üç haftalık süre içinde hastaların kar yağarken balkonda saatlerce uyuyor olmalarını, çay perhizlerini, kaliteli yemeklerini, toplumun her kesiminden insanlar geldiğini fark ettiğinde her şeyi gördüğünü düşünmüştü. Bir gün Hans, iğrenç bir durumla karşılaştı. "Kapıyı çarpan birini rahatlıkla tokatlayabilirdi. Bu olayda üstelik kapının üzerindeki küçük cam bölümler olduğu için gürültü daha da artmış hem bum diye bir ses çıkmış hem de bir şangırtı olmuştu.” ${ }^{4}$ Her firsatta yemek salonuna kapıyı çarparak giren genç bir kadının neden bunu yaptığını anlamaya çalışıyordu. İlk gördüğünde düzlükte kapının nasıl kapatılacağına dair hiç eğitim almadığını düşündü ya da hastalığı ona bunları yaptırıyordu. Kapı her akşam başka türlü çarptığı halde Bayan Clavdia, sanki hiçbir şey yokmuşçasına dostlarının bulunduğu masada yemeğine devam ediyordu. Bu bayan, "orta boylu kızılımsı sarı saçlı, beyaz

s.12. Thomas Mann, (2013) Büyülü Dă̆ (Cilt 1), çev. İris Kantemir, İstanbul: Can Yayınları.

A.g.e. s. 15

A.g.e.s. 23

A.g.e.s. 62 . 
bir süveter ve parlak renkli bir etek giymiş genç bir kadın. Saçlarını örgü yapıp özensizce dolamıştı." ${ }^{5}$ Günler geçtikçe anladı ki, ciddiyet bu topraklara ait bir şey değil, yalnızca düzlükte olur. Kaybedecek bir şeyi olmayan bu Yarım Ciğerler Derneğinin en büyük özelliği alaycı olmalarıydı. "Tanrım öylesine özgürler ki. Genç insanlar bunlar, zamanın onlar için bir önemi yok, ölebilirler de. Neden suratları asık dolaşsın ki? Bazen düşünüyorum da, aslında hastalık ve ölüm o kadar ciddi şeyler değil, bir tür başıboşluk. Yalnızca aşağıdaki düzlükte gerçek yaşamda ciddiyet var." ${ }^{6}$ Düzlükteki ciddiyetini hala bırakamamıs olan Hans, günden güne yüzünde kızarıklar çıkmaya başladı. Ateşinin bir türlü düşmemesi, üç haftalık tatilini uzatacağa benziyordu. Bir gün kuzeninin tanıştırdığı lekeli hastalardan birisi olan Settembrini, şaşkınlığını gizleyemez ve sorar: "Anlamsız ölülerin bir hiç olduğu derinlere inebilmek ne büyük yüreklilik."” Hans’a göre Settembrini hümanist ve pratik dehanın temsilcisi olan bir edebiyatçıyı hatırlatıyordu. Gelenekle tüm bağlarını koparmış olan bu edebiyatçı, roman boyunca aydınlanmanın temsilcisi gibi sanatoryumdaki tüm gelenekçilerle savaşmaya hazırdı. "Umarım hınzırlığa karşı değilsinizdir mühendis bey. Benim gözümde hınzırlık, karanlık ve çirkin güçlere karşı en pırıltılı silahtır. Hınzırlık beyim, eleştirinin ruhudur ve eleştiri ilerlemenin ve aydınlanmanın özünü sağlar.” Ölüme yakın olan bir hasta için fazla cüretkâr sözler ediyordu. Yetmemiş gibi devam etti. Aydınlanmanın düzlüklere kadar yayılması için ilk olarak hümanistlerin insanları eğitmesi gerektiğini söyledi. "Biz hümanistlerin hepsinin kanında eğitmek vardır. [...] Bir hümanisti eğitmekten yoksun bırakmamalı, bırakılamaz da, çünkü insanlığın onurunu ve güzelliğini sürdüren yalnızca odur." Hans Coastorp kuzeniyle dinlenme kürleri uygularken zamanın neden bu kadar hızlı aktığını sorgulamaya başladı. Düzlükten farklı olan neydi burada? Zaman denilen şey mekâna bağlı mıydı? Mekânı duyularımızla görebiliyoruz da zamanı hangi duyumuzla algılıyoruz? Ardı arkası kesilmeyen sorular ilk kez Hans tarafından tıpkı modernist bir insanın zihninin reddedemediği gibi soruları kendi kendine tartışmaya başlar olmuştu. Yukarıdakilere özgü bu sorgulayış, düzlükten daha fazlaydı, çünkü Hans’ın önceleri bunları soracak hiç zamanı olmamıştı. Zaman o kadar yavaş akıyordu ki, onun varlığından dahi haberdar değildi. Bir gün akşam yemeği sırasında yemek salona gelen Herr Albin, öleceğini anlamıştı. Doktorlar hangi tedaviyi uygularsa uygulasın ciğerlerindeki lekeler bir türlü geçmek bilmiyordu. İşte ilk kez genç kahramanımız Hans, ölümün getireceği baskıları düşlemeye başladı, çünkü biliyordu ki yolculuğundan beri devam eden ateşi bir türlü düşmek bilmiyordu. "Bir insanın onurun verdiği baskılardan kurtulabildiğinde, ayıbın getirdiği sonsuz yararların tadını çıkarmasının nasıl bir şey olabileceğini düşlemeye koyuldu ve kalbinin bir süre, daha hızlı çarpmasına neden olan ahlaktan yoksun tatlı bir duyguya kapılınca da dehşete düştü." ${ }^{10}$ Diğer masalardan yükselen sesler geçen gün bir gencin muayeneden sonra kendini ormanda astığının haberini veriyordu. Sanatoryumdaki bu insanlar, ölümle nasıl bu kadar iç içe olabiliyorlardı. İntihar, yemek masasında konuşulacak şey miydi? Bir an önce buradan gitmem gerek diye düşündü Hans, çünkü yaşama sadık davranmak

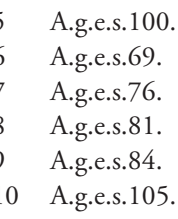


istedi. Yukarılar sadece ölüm ve yokluk kokuyordu. Düzlükte o kadar dert varken, neden şimdi oturup deneyimlemeyeceği bir şey hakkında kafa yormaya başlamıştı. Bir yönden de durumu gittikçe kötüye giden kuzenini de yalnız bırakmak istemiyordu. Her dakika olan ölümler, sanatoryuma yeni gelen hastalar, balkonda karın altına saatlerce yatay pozisyonda yaşam kürleri uygulamak, zengin akşam yemekleri Hans için fazla hareketli olmaya başlamıştı. Settembrini yaşını öğrenmeye çalıştığında yirmi dört olduğuna inanmıyordu, çünkü Hans burada kaldığı birkaç hafta boyunca, kendini yirmi dört yaşından büyük hissetmeye başladı. "Sizin bu yukarınız çok hareketli. Görecek, duyacak öyle ilginç şeyleriniz var ki, ayrıca bir gün değil de çok daha uzun süredir buradaymışım gibi geliyor, sanki daha da yaşlandım ve olgunlaştım." ${ }^{11}$ Mantıkla cesareti birleştiren Hans, Settembrini ile sohbeti olduğu akşam ilk ateşli nöbetini geçirmişti. Yeni tanıştığı hastalıklı bu bey, Hans’a öneride bulunarak bir önce eşyalarını toplayıp yaşama dönmesini söyledi. "Burada kalışınız size hem bedensel hem de ruhsal açıdan iyi gelmediğine göre burada yaşlanmaktan vazgeçip, bu akşam bavulunuzu toplayıp yarın sabahki ekspres trenlerden biriyle gitseniz nasıl olur?" 12 Hans'ın bu kadar değişiklik karşısında şimdilik gitmeye hiç niyeti yoktu. Yatakta ateşinin düşmesini beklerken, ciğerlerindeki lekeler, yükselen ateş Hans’ı bir tedavi yolu seçmeye mecbur bırakmıştı. Ya düzlüğe inip oradaki doktorlara görünecek ya da kuzeninin doktoru Behrens'e kendini tedavi ettirecekti. Oysa Settembrini'ye göre buradaki tedavinin hiçbir yararı olmayacaktı.

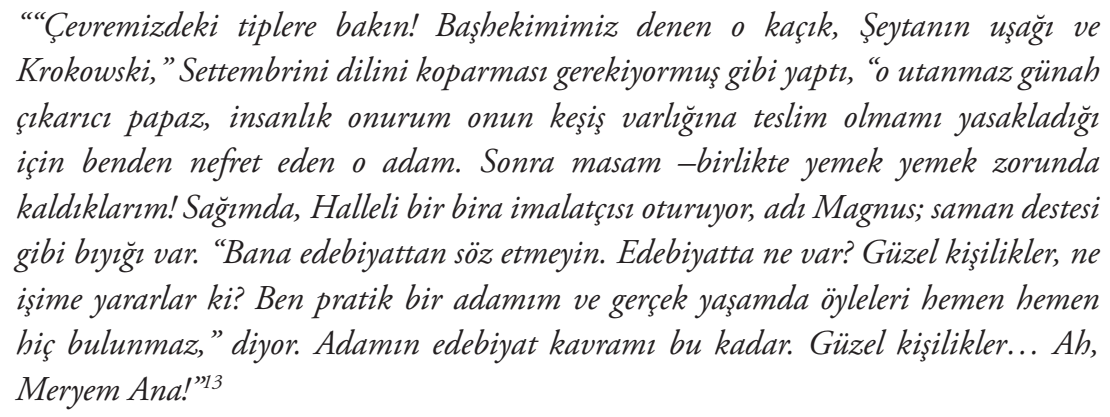

Settembrini'in önerisini düşünürken bir yandan bir değişiklikle daha karşılaştı. Ağustosun ortasında bir anda kar yağmaya başlamıştı. Düzlükten oldukça farklı olan bu düzensizlik, olsa olsa yalnızca yukarılara özgü olabilir. "Burada mevsimler birbirine karışıyorlar, takvimle ilgileri yok. Kışın öyle sıcak olur ki yürüyüşe çıktığında terleyip ceketini çıkarmak zorunda kalırsın, yazın ise eh, burada nasıl olduğunu gördün. Sonra kar gelir ve her şeyi alt üst eder.” ${ }^{14}$ Hastaların tedavisinde kullanılan bu hava olsa olsa hastalığın artmasına neden olabilirdi. Doktorlara göre ise mevsimlerdeki bu düzensizlik, insanın ruhunu ve bedenini düzenleyecek en iyi şey diye görülüyordu. Doktorlar için önemli olan hastalık değildi, hastalıkla gelen aptallıktı, yoksa hastalığın kendinde soyluluk ve incelik vardı. Settembrini'e göre ise hastalık soyluluk getiren

11 A.g.e.s. 110.

12 A.g.e.s. 112.

13 A.g.e.s.123.

14 A.g.e.s. 121. 
bir şey değildir aksine eski zamanların boş inançları ve korku çağlarından kalma hortlaklardan birisidir. Bu hortlak, insanlara ciğerlerindeki lekelerini kabul ettiren üstüne üstelik sanatoryumda bütün mal varlığını bu uğurda harcamasına neden olan deliliklerden birisidir. "Mantık ve aydınlanma insan ruhunda çöreklenmiş olan gölgeleri kovdu ama tam anlamıyla değil; bugün bile bu mücadele sürüyor." ${ }^{15}$ Settembrini ve Hans Castorp arasındaki bu konuşma, ilerlemenin ve uygarlığın önüne geçecek her türlü hastalıkla mücadele edeceğine söz vererek devam eder. Karanlık çağlardan basmakalıp kalan hastalık, insanlık için zedeleyici, onur kırıcıdır. Settembrini karanlıktan çıkan bu hortlağı soyluluk olarak görenlerin ilerlemeye, entelektüel olana yalnızca zarar verdiğini düşünür. Sanatoryumda yetkililerin hastalara bu soylu bakışı, hem bedenlerini hem de ruhlarını iyileştirdikleri yönünde pekiştirilir. Oysa Settembrini için bu lekeli hastalar sadece bedenlerine odaklanmışlardır. Ölümle iç içe olan bu insanlardan zaten ruhlarıyla ilgilenmeleri beklenemezdi. "Bedeni olmayan ruh, ruhu olmayan bir beden kadar insanlık dişı ve ürkünçtür."16 Sadece bedenleriyle dolaşan bu gelenekçiler, Hans’a göre zamanın ne olduğu konusunda da yeterince emin değillerdi, hatta onlar için yalnızca önemli olan şey tedavileri ve bol sohbetli geçen akşam yemekleridir. Beden ve ruh bütünlüğündeki insan, zaman duygusu ve yaşam duygusu süreklidir. Hans Castorp için yaşama bağlı olmak beraberinde zaman içinde olmayı da getirmektedir. Birisinin aksaması durumunda insanı can sıkıntısı gibi bulanıklığın içine iter.

"Can sıkıntısı denen şey, aslında zamanın tekdüzeliğinin neden olduğu sağlıksız bir kısalmadır ve kesintisiz bir değişmezlik, geniş zaman alanlarm, kalbi korkudan öldürecek denli daraltır ve her gün öbürünün ayn ise, tüm günler bir güne indirgenir ve kusursuz bir tek türlülük en uzun ömrün bile, göz açıp kapayana dek geçmiş bir kisalikta algilanmasina neden olur."'7

Zamanın aktif olmadığı durumlarda ise alışkanlık dediğimiz şey kendisini gösterir. Yaşamda olup zamanda olamayan veya zamanda olan ama yaşamı hayatına katamayan insanlar için alışkanlık kaçınılmaz olacaktır, çünkü onlardaki can sıkıntısı değişikliği değil alışkanlığı, sıradanlığı getirecektir. Yarım Ciğerler Derneğinin yaşamdan bu kadar uzak oluşları ve zamanı cömertçe kullanmaları hem Hans için hem de Settembrini için tutkudan uzak yargıların habercisidir. "Gerçek mevsimler yok. [...] Birbirine karışmış yaz günleri ve kış günleri var. Ayrıca geçtiğini fark ettiğin gerçek zaman olmadığı için yeniden kış geldiğinde yeni kış oluyor ama aslında eskisi geliyor ve pencereden bakarken duyduğun huzursuzluğun nedeni de bu." ${ }^{18}$ Dağdaki sanatoryumun müziğin büyüsünden uzak olduğu bir dönem Hans ve Settembrini müziğin aydınlanmaya yardım edeceği veya etmeyeceği konusunda tartışma yürütürler. Hans, insanın sırtına yük olan birbirine benzeyen saatleri ayırmanın tek yolunu müzikte bulur. Her parçanın içindeki hikâye, dakikaları fazlasıyla doldurmuş oluyor. Buradaki zamanı yavaşlatabilmenin tek yolu budur. Oysa Settembrini için müzik, hem siyasal hem de ahlaksaldır. İlkini oldukça

15 A.g.e.s.125-126.

16 A.g.e.s. 126.

17 A.g.e.s. 133.

18 s.93. Thomas Mann, (2013) Büyülü Dăg (Cilt 2), çev. İris Kantemir, İstanbul: Can Yayınları. 
sakıncalı bulurken ikincisine duyguları uyandırma açısından değer vermektedir. "Şeytani bir etki beyler. Uyuşturucular şeytan işidir çünkü durgunlaştırırlar, hareketsizleştirirler ve kölelere özgü bir durağanlığa neden olur. Müzikte kuşku uyandıracak bir şey var beyler." ${ }^{19}$ Settembrini tarafından saptanan müziğin bu uyuşturucu etkisi romanın sonuna değin genç kahramanımız Hans'ı da büyüsü altına alıp hareketsiz kılacaktır. Hatta onun hiç yapmak istemediği şeylere maruz bırakacaktır. Hans'ın yemek masasında dostlarıyla yaptığı tartışma devam ederken saflığa duyulan iç titretici özlemi duyumsar oldu. Düzlükten bu kadar uzaktayken bu özlem de nereden çıkmıştı. Yukarılara ait bir korku olmalıydı, kendini tartışmanın seyrine veremeden kafasını isteksizce çevirme ihtiyacı hissetti.

“Güm! Dedi yaşlı kız. İşte o! İçeriye kimin girdiğini anlamak için bakmak gerekmiyor. Tabii geliyor işte. Ne de hoş yürüyor! Süt kâsesine doğru süzülen bir kedi yavrusu gibi." ${ }^{20}$ Hans için bu kez çarpan kapı sesi kalp atışlarının hızlanmasına neden oluyordu. Üzerindeki utangaçlığı bir türlü atamadığı için Bayan Clavdia’yı sadece kapı sesinden yemek masasına kadar takip edebiliyordu. Yemek masasındakiler bu bayanın buraya üçüncü gelişi olduğunu söyledikten sonra Hans için çok daha önemli bir detayı vermeyi atlamadılar. "Bildiğimiz gibi Rusya'da bir yerlerde kocası var- burada bunu bilmeyen yok. [...] Rus kadınlarının doğaları gereği özgür ve cömert olduklarını çok iyi bilirim.” ${ }^{21}$ Hans bu sözleri işitir işitmez, tenindeki ateş, otuz sekizi geçmişti bile. Sevgisinin karşılıksız kalacağını bilmesine rağmen şimdi burası, düzlükten daha hoşuna gider olmaya başlamıştı. Tek korkusu bu içten sevgisinin ciğerlerindeki lekeden daha fazla şeylere sebep olmasıydı. Ahlaki açıdan yapılan şey aykırı olsa da kendi içinde yaşadığı sürece bunun kimseye bir zararı yoktu. Bu yüzden onunla tanışacak tüm yolları, daha tatil süresi bitmeden kapatmaya çalışıyordu. "Zavallı Hans Castorp'un eli ayağı titredi. Aslında ona acımamız gerekir. Bunun böyle olmasını isteyen de ayarlayan da o."22 Geldiği günden beri ateşinin düşmek bilmez durumu, kalbinin her kapı çarptığında yerinden çıkacakmış gibi olması, kuzeninin ölüme adım adım gidişi gibi nedenler Hans için oldukça ilginç olmaya başlamıştı. Daha önce düzlükte bu kadar olayı bir arada dahi görmemişti. Aşk acısı, ölüm korkusu, yaşam ve Settembrini ile olan sohbetleri, düzlükteki sıradanlıkla karşılaştırdığında, tatilinin süresini uzatması gerektiğini düşündü.

Hans, kuzeniyle karın altında uyumaya çalışırken Settembrini dinlenme tedavisini yarıda keserek, onlara teknoloji ve ahlak arasında bir bağlantının olup olmadığını sordu. Hans ve kuzeni şimdiye kadar bu soru üzerine düşünmediklerini fark ettiler oysaki Settembrini için barut ve matbaanın icadı teknolojinin gelişmesine katkıda bulunduğunu ve insanlar arasında ortak ahlaksal ilkelerin sağlanması adına teknolojinin büyük rolü olduğunu dile getirdi. "İnsanlık karanlıktan korkudan ve nefretten arınmıştı ve artık ileriye ve yukarıya doğru mutlak anlama, içsel aydınlanma, iyilik ve mutluluk aşamasına ulaşmıştı." ${ }^{23}$ İlerlemenin aracı olan teknoloji, karanlıkta

19 s.146. Thomas Mann, (2013) Büyülü Dă̆ (Cilt 1), çev. İris Kantemir, İstanbul: Can Yayınları.

20 A.g.e.s. 171.

21 A.g.e.s.171-173.

22 A.g.e.s. 183.

23 A.g.e.s. 195. 
kalmış doğu toplumları için geçerli, ulaşılabilir bir ahlaksal ilkeyi sağlamak gibi görevleri vardı. Teknolojinin şeytan işi olduğunu söyleyenler Settembrini için hareketsizlik içine hapsolmuş toplumların en büyük söylemleridir. Yaşam ve zamansal algıları bir arada çalışmayan bu insanlar, "bir dünya cumhuriyetinin" ${ }^{4}$ kurulmasına ayak bağı olmaktan başka işleri yoktur. Teknoloji ve ahlak arasındaki bu daimi süreklilik Settembrini'a göre hümanizmin olmazsa olmazıydı. Aydınlanmadaki insan ne cesaret sahibi olabilir ne de evrensel ahlak ilkelerini kurabilirdi. Hans büyük şaşkınlık içinde Settembrini'yi izlerken zihninde, daha önce bu kadar cesur bir insan görmediğine emindi. Düzlükte zaten karşılaşsaydı konu hiçbir zaman ne hümanizme ne de ahlaka gelecekti. Böyle bir insanın ciğerlerine tüberküloz nasıl olup ta yapışmıştı. Yaşama olan tutkularını kaybetmiş hastalardan farklı olan Settembrini sadece bedensel olarak hastaydı. Sanatoryum onun ruhunu ele geçirmeyi bir türlü başaramadı. Bir yandan da düşmek bilmez ateşinin test sonuçları doktorun eline ulaştı: "Ama baştan söyleyeyim ki sizin gibi bir vaka kolay iyileşmez. Reklam olsun diye başarılar ve mucize tedaviler sağlamıyoruz. Sizin bir konuk olmaktan çok hasta olmaya yatkın olduğunuzu söyleyebiliriz." ${ }^{25}$ Hans bu görüşmeden sonra konuk olmayı bırakıp hasta olmaya alışması gerekirdi, zaten anne babası olmayan bir gencin sağlıklı olmaya da hakkı yoktu. Sanatoryumda artık o da ölecekler listesinden birisi olmuştu. Böylece doktorlar onunla sohbet etmek için değil bu kez ciğerlerindeki hırıltıları dinlemek için randevu vermeye başladılar. Settembrini, Hans’ın filmlerindeki lekelerin bazen gerçek olamayacağ uyarsa da bir önce gitmesi için ikna edemedi.

"Filmde çoğu zaman leke diye gösterdiklerinin aslında gölge olduğunu ve gerçekten bir şey olduğunda hiçbir şey göstermediklerini biliyor musunuz? Ah Madonna! Filmmiş! Burada genç bir finans uzmanı vardı ve ateşi olduğu için filminde lekeler rahatça görülebiliyordu. Onları duydukların bile iddia ettiler! Verem tedavisi gördü ve öldü. Otopside ciğgerlerinde bir şey olmadiğg ve bilmem ne virüsünden öldüğ̈̈ anlaşıldı. '26

Hans, zihninin hiçbir şekilde karışmayacağına, yaşamla olan dostluğunun devam edeceğine sadece tedavi amacıyla kalma süresini uzattığını iddia etse de yapacakları karşısında Thomas Mann bile hayretler içinde kalacaktır. Bir gün tedavi sırasında doktorun odasındaki portreye gözleri yönelir. Gördüğünün Kırgız gözlü kadın olduğuna emindi. Hayretler içinde kaldı. Birine konuk olarak gitmek, hem de portresini yaptırmak görgü görmüş bir kadının işi olamazdı. Oysa Hans haftalardır ona merhaba bile diyememişti. "Sağduyu ve onuruna olan düşkünlük Hans Castorp'un yüreğini sızlatıyor, özdenetimini birazcık artırıyor ve o çekik gözlü kişiden, 'bir kalem istemesini' önlüyordu." ${ }^{27}$ Bayanın, başhekime modellik yapması ateşinin artmasından başka bir şeye yaramadı. Muayene odasından çıktığında daha acı bir gerçekle karşılaştı; ciğerlerindeki hırıltıların nedeni anlaşılamamıştı. Bu dinlenmeye, sabırlı olmaya, ateşini ölçmeye, uyumaya ve beklemeye devam etmesi anlamına geliyordu. Geleli yedi hafta olmasına rağmen sanki bu sabah trenden inmiş gibi hissediyordu. Artık düzlüğe dönmeyi kafasından atmıştı. Bu belirlenemeyen

24 A.g.e.s. 197.

25 A.g.e.s. 227.

26 A.g.e.s. 245.

27 A.g.e.s. 258 . 
lekelerle düzlükte bir saat dahi yaşayamazdı. Hem şimdi Bayan Clavdia’yı bırakıp gidemezdi. En büyük kaygısı olan lekelerine bir yenisi daha eklenmişti. Tıpkı zihninden atamadığı bir düşünce gibi gözlerini Clavdia’dan ayıramıyordu. "Başını öne doğru uzatışını, disiplin ve terbiyenin verdiği enerjiden yoksun olmasından öte bir nedeni olmadan ve hiç özür dilemeden geç kalışlarını izliyor, yine aynı temel nedenden girerken de çıkarken de kapıyı çarptığını, ekmeği ufaladığını ve ara sıra tırnaklarını yediğini görüyordu." ${ }^{28}$ Hans, hastalık ve aldırmazlık arasında bir bağlantı olabileceğini düşündü. İnsanın hastalığı arttıkça daha fazla umursamaz olmaya başlıyor ve yargı yetisini dışarıda bırakıyordu. Ateşi yükseldikçe, iki büklüm oturuyor, yemek salonundaki kapıyı kapatma gereksinimi duymuyordu. "Hans Castorp'un içinde bulunduğu durum genelde, ortaya çıkmak için dayatan bir durumdur; itiraflara yatkındır ve insana kendisine yönelik kör bir beğeni ve dünyayı kendi varlı̆̆ıyla doldurma hırsını getirir." ${ }^{29}$ Clavdia ve Hans'taki bu nezaketsizlik Settembrini için yaşamdan yavaş yavaş koptukları anlamına geliyordu. Diğer hastalar gibi onlarda ya zamanda ya da mekânda olmayı tercih ediyorlardı. Ruh ve bedenin birbirinden bu kopuşu Settembrini için yemek salonundaki sıkıntının tek nedeniydi. Hepsi birbirine bakıp bir şeyleri moda haline getiriyorlardı. Dün kapıyı kapatmazken, bugün ekmeklerini ufalıyorlardı. Tüberküloz gitgide bedenlerini hapsetmekle kalmıyor ruhlarını da esir alıyordu. Estetik ve ahlaktan yoksun bu insanlar, zamanı insanlığın ilerlemesi için değil sadece yemek ve dinleme diyetleriyle dolduruyorlardı. Sorumluluğu alma cesaretinden yoksun hastalar, insanlığın dostu değil olsa olsa şeytanı olmuşlardır.

"Özgürleşmeye, güzelliğge ve duyguların, mutluluğun ve arzunun özgürlüğ̈̈ne hizmet ettiği sürece onu savunmalı ve ona sayg göstermeli; ama ışı̆̆a doğru akışı engelleyen yer çekimi ve dură̆anlık, hastalık ve ölüm ilkelerini temsil ettiği ve sapıklĭ̆ın, bozulmanın, şehvetin ve rezaletin temeli olduğgu sürece onu hor görmek gerekir."’o

Zamanı tüketmeyi çoktan öğrenmiş bu insanlar yemek yerken kitap okuma isteklerini giderebilmek için dizlerinin üzerine kitap açmayı ihmal etmiyorlardı. "Neydi yaşam? Bilen yoktu. [...] Neydi yaşam? Bilen yoktu. [...] Yaşam aslında neydi? Yaşam, var olması olanaksızın var olmasıydı." ${ }^{31} \mathrm{Bu}$ sanatoryumda olanaklı olanın dahi kendisini sürdürememesi, yaşamın değil ölüm ve tehdidin var olmasından başka bir şey değildi. "Yattığı yerden yünler ve kürkler içinde beden sıcaklığını korurken, buz gibi bir gecede, ölü bir yıldızın 1şığıyla parıldayan vadiye bakan Hans Castorp'un önünde yaşam işte böyle bir resim verdi." ${ }^{32}$ Dostlarıyla birlikteyken, bir zamanlar mühendis olacaktım dedi. Düzlüğe bir daha geri dönemeyeceğini kabul etmeye çalıştı. Şimdiki hedefi hastaları izlemek, yeni kitaplar okumak ve düşünülmemişler üzerine kafa yormaktı. Hem hasta olup hem de her şeye bu kadar merak salmak Settembrini için olacak şey değildi. "Siz yaşamın sorunlu çocuklarındansınız, ilgilenilmesi gerekenlerdensiniz." ${ }^{33}$ Roman boyunca yaşamın sorunlu çocuğu olarak kalan olan Hans, kasabada kaldığı günleri saymaktan

28 A.g.e.s.284.

29 A.g.e.s.294.

30 A.g.e.s.311.

31 A.g.e.s.341.

32 A.g.e.s.342.

33 A.g.e.s.380. 
vazgeçti. Noel gecesi sanatoryumdaki kutlamaya katılan Clavdia, Hans’ın yedi aydır yapamadığı şeyi yaparak, ondan bir kalem istedi. Aralarındaki yakınlık onları dansa kadar sürükledi. Clavdia, müzik eşliğinde yarın sabah köyden ayrılacağını söyledi. İyileşememesine rağmen başka temiz havaları denemek en özgür isteğiydi, çünkü ona göre "insan, kendini kurtarmak yerine kendini bırakmalı ve yıkılmasına, hatta ezilmesine izin vermeli." ${ }^{4} 4$ Hans’a göre şuan bunların hiçbir önemi yoktu. Tek düşündüğü şey karşısındaki kadının kollarında olduğuydu. Derin konular üzerine konuşmak için uygun bir zaman değildi. "Seni seviyorum, diye geveledi. Seni her zaman sevdim çünkü sen benim yaşamımın sen’isin, düşümsün, yazgımsın, tüm isteğim ve sonsuz özlemimsin. [...] Umurumda değil dedi. Ne Carducci, ne güzel üslup cumhuriyeti ne de insanlığın zamanla ilerlemesi-çünkü seni seviyorum!" ${ }^{35}$ Her şey herkesin başına gelemeyeceği gibi, genç kahramanımızın da yüreğindeki sevgi, onu yaşam ve zaman tutkusundan alıkoyan bu sanatoryumda tek destekçisi olacaktır.

Sanatoryumdaki zengin hastaların ruhu ve bedeni lekelerin dışında bu kez de karla yok olmaya başlamıştı. Gereğinden fazla kar, onların zarar görmesine neden oldu. Hatta gözleri daima beyazı görmekten bozulanlar vardı. Dışarıdayken renkli gözlükler takıp, odalarının pencerelerine yeşil doğa manzaraları yapıştırıyorlardı. "İnsan dayanamazdı buna; insanın hem zihnini hem de ruhunu öldürüyordu." ${ }^{36}$ Settembrini, insanın yüreğini kirleten bu kadar şeye nasıl tutkuyla katlandıklarını bir türlü anlayamadı. Onlara göre tamamen iyileşememiş birisi, temel kavramların olmadığı bir yerde nasıl yaşayabilirdi ki? İyileşse dahi Clavdia’yı beklemek için Davos'ta kalacağını söyleyen Hans, artı düzlükle olan tüm bağlarını koparmıştı. Ailesinden sanatoryumun masrafları dışında bir şey istemiyordu. Settembrini için ise o, yaşamın sorunlu bir çocuğu değil, "Ahlakı, mantıkta ve erdemde arayan birinin gözünde büyük bir olasılıkla kayıp biriydi artık." ${ }^{37}$ Romanın başlarında oldukça tutkulu olan Hans, Clavdia’nın aşkından sonra aydınlanmamak için direnen, hümanist değerleri reddeden kayıp biri olmuştur. Aşk, onu öznelleştirerek evrensel ilkeler öne sürmesini engellemiştir. Şimdi o da Yarım Ciğerler Derneğine rahatlıkla üye olabilirdi. Sevgi onu özel kılmasına rağmen sadece bedeninin arzularına önem verdiği için Settembrini tarafından çok eleştiri aldı, çünkü asıl olması gereken ruh ve beden bütünlüğü içerisinde hümanist değerler yaratabilmektir. Gerisi ilerlemeye ket vuran inançlı birisinin tutkusuyla aynıdır. Tüm bu görüşlere şiddetle karşı çıkan Settembrini daha fazla kalamazdı orada. Zaten tedavide hiçbir gelişme de olmuyordu. Yoğun karanlığın, ışığını kapatacağı korkusuyla bir gün sanatoryumdan ayrılmaya karar verdi.

\section{"Kızakla değil yürüyerek ayrılmıştı sanatoryumdan. Üzerinde, kollarına ve yakasına ince bir kürk şerit geçmiş kısa sarı paltosu, bu dünyadaki mal varlı̆̆ın ve yazarlık malzemesini el arabasında taşıyan bir adamın eşliğinde, kapının önünde bir salon kızının yană̆ından bir makas aldıktan sonra bastonunu sallayarak uzaklaştığı görülmüşı̈̈."’8}

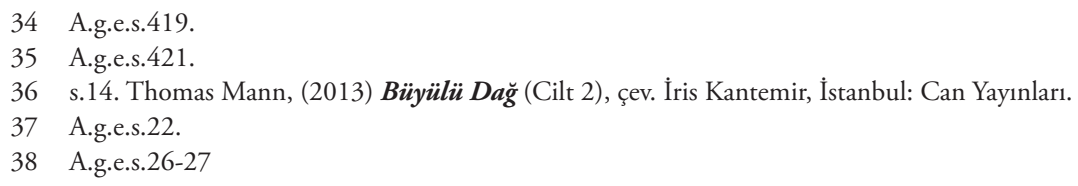


Onun odasını doldurmak için düzlükten hemen bir hasta getirildi. Kuzen Joachim ise o sıralarda düzlükteki askerlik hayalini gerçekleştirmek için dinlenme ve tedavi diyetinde hiç aksatma yapmıyordu. Nihilizm ve kötülüğün tüberküloz salgını gibi yayıldığı bu yerde Settembrini her şeye rağmen anti nihilist değerlerle düzlükte tartışma toplantıları yapmaya başladı. Bir yanda meraklı Hans ve savaşa katılma arzusuyla yanan Joachim diğer yanda üst komşusu bir din adamı. Tartışmanın başlaması için tüm malzemeler hazırdı. Tabi ki ilk konu günlerce balkonlarındaki şezlonglarında dinlenmenin insana getireceği kötülük oldu. Hans tartışmanın yarattığı heyecanla konuşmaya girmiş bulundu. "Yatağım-yani şezlongum demek istediğimi anlamışsınızdır-son on aydır çok yararlı oldu çünkü benim düzlükte o kadar yıldır düşündüğümden çok daha fazlasını düşünmemi sağladı." ${ }^{39}$ Sözleri duyan Settembrini coşkuyla yerinden kalktı ve neden bir batılı gibi davranmadığı sordu. İlerleme, aydınlanma, analiz, akıl bu kadar önemliyken bir keşiş gibi bu yatağa düşkünlükte nereden çıkmışı. Hans, katıksız bir barış taraftarı olduğunu söyleyerek tartışmadan çekilme kararı aldı. Settembrini' in üst komşusu olan Naphta, papazlık yaptığı dönemleri hatırlayarak keşişe edilen hakaretleri üzerine aldı. Tüm dini görevlerini yerine getirse de ciğerlerindeki lekeler rahip olmasını engellemiştir ama dostları arasında lekeli hoş bir Cizvit olarak anılıyordu. Settembrini, komşunun tartışmaya girmesi için öncelikle Pan-Germanizm düşüncesinden sıyrılması gerektiğini düşündü. "Nefret etmeye ulus devletten başlamazsanız mantığınızda bir boşluk var demektir." ${ }^{40}$ Evrensel cumhuriyetçi değerleri yıkan birisiyle tartışmaya girmek gereksiz olacaktı. Naptha, söze Tanrı devletinin kurulmasıyla evrensel mutluluk ilkesinin geleceğini söyleyerek giriş yapmış oldu. Irkının verdiği içgüdülerle hareket ederken, Tanrı'nın en büyük isteğinin ulus devletleri arasındaki sınırların korunması gerektiğini söyleyerek eklemede bulundu. Settembrini büyük bir kızgınlıkla Haçlı Seferleri'nin insanlığa getirdiklerini sordu. Naptha her ne kadar ticaret, kültürel kaynaşma gibi olumlu ifadeler sarf ettesede, Settembrini, insanların birbirlerinin üzerinde hâkimiyet kurma arzusunu körüklediğini ekledi. İnsanlığa iyi olmayı değil, kötülügü öğreten savaşlar, nasıl olur da Tanrı’nın en büyük arzusu olabilirdi. Komşusuna sadece şu öneride bulundu: "İnsanın başlangıçta iyi, mutlu ve kusursuz olduğunu ama toplumsal yanılgılar sonucunda yoldan çıkıp bozulduğunu ve toplumu yeniden eleştirel bir bakış açısıyla yapılandırdığında yeniden iyi, mutlu ve kusursuz olacağını savunan 18. yüzyılımızın düşünce biçimi sizi rahatlatabilir”¹ dedi. Hans tartışmalar arasında dünya cumhuriyetini savunan Settembrini mi yoksa hiyerarşik kozmopolitanlığ savunan Naphta'dan mı yana olacağının kararını veremedi. En iyisi taraf olmadan sanatoryuma geri dönmekti.

"Biri, bir yandan uluslararası Dünya cumburiyetini savunup savaştan nefret ederken bir yandan da öylesine vatansever ki tek sınır olarak Brenner Geçidini kabul ediyor ve bunun için uygarlık savaşında savaşmaya hazırken, öbürü ulus devletinin şeytan işi olduğunu iddia ediyor ve tüm inşaların birleşmesini isterken doğal içgüdüler yasasını savunuyor ve barıs konferanslarıla dalga geçiyor. "²

39 A.g.e.s.48.

40 A.g.e.s. 53 .

41 A.g.e.s. 55.

42 A.g.e.s.60. 
Kuzeni yalnız olarak döndü ama Hans Settembrini'in yoğun isteğiyle biraz daha kalmayı kabul etti. Tartışmanın nabzını düşürebilmek için Naphta’nın evine üst kata çıktılar. Naphta’nın evi, Ortaçağ dönemdeki Tanrı'nın evinden farksız gibiydi. Din adamlarına özgü zenginlik ve zanaata düşkünlük misafirlerini şaşkınlığa uğramıştı. Settembrini isteksizce salonda duran heykeli kimin yaptığını sordu. Naphta misafirini kışkırtırcasına; "Ne fark eder ki, dedi. Sormamamız bile gerekir çünkü yapıldığı zaman da kimse sormamış. Yazarı belli olmayan bir kitap gibi anonim, ortak bir ürün.” ${ }^{43}$ Settembrini bu sözleri işitir işitmez heykele arkasını dönerek oturdu. Hans ise daha önce böyle büyüleyici bir sanat yapıtıyla karşılaşmadığına yemin etti. "Hiçbir şeyin bu kadar çirkin, özür dilerim ama aynı zamanda bu kadar güzel olabileceğini düşünemezdim” ${ }^{44}$ dedi. Naphta ise güzel ve çirkin en iyi şekilde dinsel ifadelerle ortaya konulmalı diye eklemede bulundu. Settembrini için ise bu doğaya yapılmış en büyük ihanetti. Nasıl olur da dehanın yaratıcısı göz ardı edilmişti. Zaten bu çalışma olsa olsa savaşı arzulayan bir adamın elinden çıkmış olmalıydı. "O dönemin ne tür insanlık dışı bir dehşet ve kana susamış bir hoşgörüsüzlük getirmiş olduğunun da farkındasınızdır. Bunlar olmasaydı arkamda duran şu eski yapıt da olmazdı” ${ }^{5}$ dedi. Naphta kan bulaşan ellerini temizlemek için tüm bunların sevgi uğruna yapıldığını söyledi. Settembrini ise oturduğu yerden kalkarak heykeli tamamen kapattı ve nasıl olurda ahlaksal en yüksek iyiyi verecek olanın kilise olduğunu söylemeye çalıştığını sordu, çünkü ona göre asıl önemli olan insandı. "İnsanın yararına olan her şey gerçektir. Doğa onda özetlenir; tüm doğada yaratılan bir tek odur ve doğa onun içindir” ${ }^{46}$ diyerek insanın üzerinde hiçbir egemenin bulunmadığı görüşünü pekiştirmiş oldu. Naphta ise görüşlerini Platon'un felsefesine dayandırmakla övünmeye başladı, çünkü ona göre bu felsefe insanı Tanrı'ya götürecek tek yoldur. Zaten yıllardır Platon felsefesinin diğer düşünürlerin önünde olması Naphta’ya göre sebepsiz değildi. Settembrini ise onu fazla pragmatist olmakla suçladı. Hans bu sırada hala heykelin nasıl anonim ve ortak olabileceğini düşünüyordu, bu yüzden de tartışmanın hangi yollarda devam ettiğini takip edemedi. Naphta çayları tazelerken Ortaçağın özgürlüğüne değinmek istedi ama Settembrini olmayan bir şeyden bahsetmenin buradaki gençleri kandırmaktan farksız olduğunu söyleyerek sözünü yarıda kesti.

"Zanaatkârların ve köylülerin ne denli saygın olursa olsun toprakları yoktu, toprak sahiplerinin kuluydular. Ortaçă̆ın sonlarına dek, insanlarm çoğu, kentliler bile öyleydi. Konuşmamızın arasinda insan onurundan söz ettiniz. Oysa şimdi bireyi özgürlükten ve onurdan yoksun birakan bir ekonomik sistemin ablaklı olduğunu savunuyorsunuz." ${ }^{\text {T } 7}$

Naphta ekonominin varlığının devam etmesi için bunun gerekli olduğunu söyledi hatta sözlerinde Marx’tan (1818-1883) alıntılar yaptı. Settembrini, Kapitali (1867) piyasadaki ucuz çevirilerden okumuşsun dedi ve daha fazla dayanamayarak Hans'ı alıp evden çıkmayı tercih etti. Yolda ona bazı ögütler vererek arasına mesafe koymasını istedi. Böyleleri insana güneşin dünyanın

43 A.g.e.s.68.

44 A.g.e.s.67.

45 A.g.e.s.70.

46 A.g.e.s.73.

47 A.g.e.s.73. 
etrafında döndügüne inandırabilirdi. Hans kafasıyla onaylama işareti yaparak sanatoryuma doğru tırmanmaya başladı. Ortaçağ ve aydınlanma dönemi arasındaki gerilimi bir din adamının salonunda canlandıran Thomas Mann, bu çekişmeden kimin galip geleceğini ise incelememizin sonunda söyleyecektir. Hans sanatoryuma döndükten sonra kuzeni Joachim, artık daha fazla dayanamayacağını ifade ederek ayrılmak istediğini açıkladı. Düzlükteki hayali tam iyileşememiş olsa dahi onu bekliyordu. Hans buraya yıllar önce onu ziyaret için gelmişti ama şimdi Joachim düzlüğe giderken, kendisi Clavdia’yı beklemesi gerekiyordu. Artık ateşini ölçmeyi bırakan Joachim dereceyi yanlışla yere düşürüp kırmıştı. Yeniden somut zamana karışmak Joachim bir an önce eşyalarını toparlayıp sanatoryumdan ayrılır ayrılmaz orduya yazıldığına dair bir hafta içinde Hans'a mektup yolladı. Hayali gerçekleşmişti, ciğerlerindeki lekelerin artması onun için önem arz etmiyordu. Tek önemli olan ulusu için savaşmaktı zaten dinlenme diyetlerinde ölümü her gün yaşıyordu, en azından düzlükte kahramanca öleceğim diye düşündü. Naphta ve Joachim arasındaki bu benzerlik Settembrini tarafından fark edilirken Hans görmemeyi tercih etti, çünkü ona göre Naphta’nın anlattıkları değerli geliyordu. Settembrini ise büyük tepki vererek ikisinin de kan dökmekle olan bağlantılarını fark etmesini istedi.

"Bizim barış çocuğu Naphta’nın gerçek keşişler olmalarına karşın, güç hırsıyla yanıp tutuşan ve Tanr devleti ve onun üst düzeydeki dünya egemenliğini gerçekleştirebilmek için kan akıtmaktan çekinmeyen savaşçı Ortaçă̆ keşişleri ya da kâfirlere karşı savaşırken ölmenin, yatağında ölmekten çok daha onurlu bir şey olduğunu savunan Tapınak Rahibiydi. "’s

Öldürmenin baş tacı edildiği bu düşünce anlayışında Settembrini, hastalığın Ortaçağ kültüründe önemli bir yere sahip olduğunu söyler. Eskiden kralın kızları, fakirlerin yaralarını hissedebilmek için yüzlerini yaralara sürermiş dedi Naphta övünerek. İsa'dan beridir acı çekmek, yoksulluk, hastalık baş acı edilirken erdem, sağlık ve akıl buradan çıkamazdı. "İnsan olmanın hasta olmakla aynı şey demek olduğunu söyledi. Evet, hastalık insanın doğasında vardı ve onu insan yapan hasta oluşuydu. [...] İnsanın onuru ve soyluluğu ruhta ve hastalıktaydı. Kısacası insan ne kadar hastaysa o kadar daha üst düzeyde insandı." ${ }^{49}$ Bu nedenle Settembrini, Naphta’nın yüzüne her baktığında bir hastayla ilgilenircesine ona acıyordu. Yaşamda değer olabilmek beraberinde sevgi, tutku, ilerleme gibi pek çok şeyi de getirmekteydi. Oysa dini yaymakla meşgul insanlar tüm yatırımlarını yoksulluk ve hastalığa harcamışlardır.

Joachim'in üniformalı fotoğrafının gelmesinden bir hafta sonra Hans bir mektup aldı. Joachim teğmen olduktan sonra hastalı̆̆ı ilerlemişti, görevine devam etmesi imkânsız bir hal almıştı. Doktorlar tarafından Alpler önerilmiş ve Joachim birkaç gün içinde orada olacağını yazmıştı. Hans işte tam da burada beden ve ruh arasındaki savaşta bedenin galip geldiğini duyurdu, hastalığı ruhunun isteklerini yok saydı. Ne derse desinler bedeni eğitmek ruhu eğitmekten daha zordur dedi Hans. Joachim hayallerinden bir kez daha vazgeçip sanatoryuma lekeleri yüzünden dönmek zorunda kaldı. "Bedenin ruha boyun eğmesi gerektiğini savunan sivri

$48 \quad$ A.g.e.s.133.

49 A.g.e.s.152-153. 
zekâlıların tam bir yenilgisi." ${ }^{50}$ Bu kez annesiyle birlikte gelen Joachim, bir an önce gerekli testler yapılarak dinlenme, yeme ve tedavi diyetlerine başlatıldı ama her an ölebilecek olması gözlerinden okunuyordu. Ciğerlerindeki leke, artık nefer almasına, yüzüne tebessüm kondurmasına izin vermiyordu. Doktorların yaptığı testler sonucunda onur düşkünü Joachim'in sadece altı ayı kalmıştı. Sanatoryumda zamanın sonsuz olduğunu düşünürsek bu süre romanda sanki dakikalar içinde gerçekleşmiş gibi aktarılmaktaydı. Ayaklarının üzerinde durmayı bile başaramayan Joachim şimdi can çekişen bir lekeliydi artık. "Akşamüzeri saat altı sularında, garip bir şey yapmaya başladı. Bileğine altın zincir takılı sağ kolunu kalçasının hizasına kadar uzatıyor. Elini biraz kaldırdıktan sonra battaniyeyi tırmalar ya da kazır gibi bir hareketle kolunu geri çekiyor, sanki bir şey topluyor ya da bir şeyleri bir araya getiriyordu." ${ }^{11} \mathrm{Bu}$ sözcükler Joachim'in son hareketleri oldu. Onur ve beden düşkünü Joachim, gümüş tabutu içinde kahraman sözcüklerinin ritimde bolca sarf edildiği Ludwig van Beethoven (1770-1827)'nın 3. Senfonisi olan Eroica (1803) eşliğinde düzlüğe uğurlandı. Hans doğuştan gelen o soğuk âdetini bir yana bırakarak kuzeninin alnını öperek vedalaştı. Kahramanlık, bedene olan düşkünlük şimdi bir tabutun içinde kızakla indiriliyordu. Kuzeninin ölümünden sonra zamanı son kez düşünmek istedi. Neydi zaman? Kaç yaşındaydı? Artık ne kaç yaşında olduğunu ne de orada ne zamandır kaldığını hatırlayabiliyordu. Tartışmaya geri dönecek olursak her fırsatta dini yaymakla görevli olduğu ve kilisenin düşüncelerinden bağımsız düşünememesi gerekçesiyle eleştirilen Naphta bu kez Hans’ı ilk boş bulduğu anda Settembrini'n aslında dini örgütlerden hiçte bağımsız olmadığını söyledi. Tıpkı o da masonluk yapıyordu hatta döneminde kurulan örgütlere başkanlık ettiği dahi olmuştu. Hans bunları duyduğuna inanamadı. Nasıl olur da ilerleme, erdem ve dünya cumhuriyetinden bahsedip masonluk yapabiliyordu.

\section{"Insanlık tapınă̆ının inşaat alanına girmesinin hiç te kolay olmadiğın tahmin edebilirsiniz çünkü beş kuruşu yok ve onlar yalnızca üst düzeyde eğitim ve hümanistik eğitimle yetinmiyorlar, yüksek aidatları ve ynllık ödemeleri yapabilmeniz için kusura bakmayın ama varlıklı olmanızı da istiyorlar. Alın size burjuvazi! Liberal dünya cumburiyetinin temelleri bunlar." 2}

Hans bu sözlerin ardından odasında daima açı duran Rivista Della Massoneria İtaliania (1885) kitabının nereden orada olduğunu bu kez anlamıştı ancak Settembrini'nin bu konuda apolitik olacağını düşündü. Naphta ise çevresinde masonluğun apolitik olduğunu söyleyenleri şiddetle reddederek şunları ekledi; "Apolitik olmak diye bir şey yoktur, her şey politikadır." ${ }^{3}$ Settembrini'in bu tartışmaya girmesi kaçınılmaz oldu. Söylenenleri reddetmedi ama örgütlerinin tek amacının Tanrı'yı yüceltmekten öte insanlığı yükseltmek olduğunu söyledi. Hatta şöyle bir örnekle pekiştirerek; "Daha yeni, bir kuşak önce, Fransa’nın büyük doğusu tüm yapıtlarından Tanrı'nın adını silerek iyi bir örnek oluşturdu. Biz İtalyanlar onu örnek aldık." ${ }^{4}$ Settembrini,

50 A.g.e.s. 195.

51 A.g.e.s. 241.

52 A.g.e.s. 211.

53 A.g.e.s.213.

54 A.g.e.s. 215. 
bu sözlerin ardından Cizvitler ve Masonlar arasındaki en büyük farkın, sözü sevmek olduğunu söyledi. Settembrini'e göre masonlar dile sahip olmakla dünya cumhuriyetini kurmanın cesaretini gösterebilirler. Özelikle bu cesaret burjuvazi sınıflarında gerçekleşmiştir, çünkü Ortaçağ insanlara hiçbir zaman bu özgür alanı sağlayamadı. "Artık uçan kuşlar bile aslında Ortaçağ manastırlarından türeme köhne okul sisteminizin yanlış bir tarihe oturtulduğunu biliyordu." ${ }^{55} \mathrm{Bu}$ tartışmalar arasında bir gün sanatoryumun yemek salonuna Bayan Clavdia ve Peeperkorn girdiler. Hans'ın yıllardır beklediği kişi sonunda gelmişti ama bu kez yalnız değildi. Hans, Clavdia’ya kuzeninin düzlükteki kahramanlığı yüzüne öldügünü söylediğinde tabii ki Bayan, Joachim’i desteleyecek sözcükler söylemekten kendini alıkoyamadı. Daima insanın bedenine olan övgüleri söylemekten çekinmeyen bu kez daha da ağır sözler etti: "Her firsatta bedeniyle ilgilenirdi. Onurlu bir biçimde demek istiyorum. Ama bedeni onurlu olmayan bir şeyin onu istila etmesine ses çıkarmadi. İşgüzarlığını üçkâğıda çevirdi. Ama insanın kendini kaybetmesi ya da mahvına izin vermesi kendini kurtarmasından çok daha ahlaklı bir davranıştır. ${ }^{56}$ Bu sözler Hans’ın karşı çıkabileceği türden değildi, çünkü yaşama isteği Clavdia'nın sanatoryuma girmesiyle artmıştı. Onun ne söylediği çok da önemli değildi.

"Düzlüğ̈̈n küçük, sakin şarkılarının olmadiğı yasak ve mantıksız bir aşktı bu. Delicesine seviyordu onu, ona bağımlıyd, onun kölesiydi ve ona hizmet etmeye hazırdı ve çok acı çekiyordu ama köleliğinin ve acısının arasında, Herr Settembrini nin, onun da farkında olduğu gibi açıkça ona karşı olduğunu belirtmesine karşın tutkusunun süzülerek yürüyen çekik Tatar gözlü için ne denli değerli olduğunu ve değerli olmayı sürdüreceğini anlayabilecek kadar da kurnazd.. ${ }^{57}$

Clavdia'ya olan bu tutkusu her gün onu yaşamdan ve sağlıktan alıkoyarken, diğer taraftan bir yol arkadaşıyla gelmesi çok canını acıtmıştı. Üstüne bu bey gereğinden fazla yetenekliydi. Hans onunla sohbet etmeyi çok sever oldu. Bu yüzden Clavdia’yla arasındaki ilişkiyi anlatma sorumluluğu hissetti. "Her şeyi unuttum, akrabalarımdan, düzlükteki mesleğimden, her şeyden koptum. Clavdia gittikten sonra burada onu beklemekten başka bir şey yapmadım ve artık düzlük varlığını yitirdi. Onun gözünde bir ölüden farksızım.. ${ }^{58}$

"Size yalan söylemek beni çok rahatsız eder ve bu nedenle bundan kaçınmaya çalışıyorum. [...] Clavdia'ya kafamda hep 'sen' diye hitap ettim gerçekten de farklı olmadı. Biraz önce sözünü ettiğimiz eğitsel baskılardan kurtulup -daha önceki bir deneyimimden esinlenerek- ona yaklaşabildiğim akşam maskelerin takıldĭ̆g, insanların birbirine sen diye hitap ettiği ve sorumluluğun olmadĭ̆g bir akşamdı. "\$9

Hans bu sözlerin üzerine yeni dostunu kırmamak adına fazladan bir gündü diye ekledi. O geceye Şubat'ın yirmi dokuzu bile diyebiliriz dedi. Peeperkorn, ise cevap verme gereği

55 A.g.e.s. 221.

56 A.g.e.s. 266.

57 A.g.e.s. 294.

58 A.g.e.s. 331.

59 A.g.e.s. 327. 
hissetmedi. Bir an önce iyileşmesi için iyi dileklerde bulunarak ışı̆̆ı kapatıp odasına doğru yöneldi. Sabah koridorda gürültülü bir telaş duyuldu. Herkes Peeperkorn'nun odasına yönelmişti. Odadan çıkarken görülen Doktor Behrens, durumunu soranlara, iyi düzenlenmiş bir intihar olarak niteledi. "Hans Castorp oturduğu yerde, alnını ve kalbinin olduğu yeri ovdu. Korkuyordu. Tüm bunların sonu iyi olmayacak, bir felaketle sonuçlanacak gibiydi." ${ }^{60}$ Yaşadığ büyüler ona yetmezmiş gibi Mann, Hans'ı düzlüğe göndermemek için kalemini oldukça zorlamaya çalıştı. Bir gün Doktor Behrens, elinde bir müzik aletiyle yemek salona girdi. Eğitimsiz bir pazarlamacı gibi gramafonu öven doktor, hastaların keyif almasını için onlara emanet etti giderken de Jacques Offenbach (1819-1880)'ın büyüsünü bıraktı. Can çekişen Hans, büyüyü tekrar ettirmek için Hoffmann'ın masallarından Barcarole (1881) ile devam etti. Aşkı betimleyen bu opera, Hans'ın düzlükteyken nasıl âşı olduğunu hatırlattı. "Hissettikleri bir gencin kıza ilk kez baktığında Eros'un dikenli okunun ansızın yüreğine saplanmasında hissettiklerinden aşağı kalır yanı yoktu ve artık her adımının altında kıskançlık yatıyordu." ${ }^{6}$ Bu zevk dağıtıcı alet, tüm sanatoryumda ses getirmeye devam etti. Hans başından ayrılmamak için tüm eşyalarını müzik odasına taşıdı. Gece boyunca bir köle ve mısır prensesinin aşkını anlatan Giuseppe Verdi (1813-1901)'nin Aida (1871) operasını dinledi. "Kutudan yükselen ses her ne kadar çok daha güzelse de Hans Castorp’un zihninde hüzün verici tanıdık bir adla özdeşleşiyordu." ${ }^{2}$ Sıradan kahramanımızın ölümüne dair taşıdığı kuşku müziklerdeki büyüyle daha da artmaya başlıyordu. "Bu büyülü şarkı uğruna ölmeye gerçekten değer. Aslında, bu şarkı yüzünden ölmez ölen. Yeni bir şey uğruna, sevginin ve yüreğindeki geleceğin yeni sözcüğü uğruna ölür ve bir kahraman olur." ${ }^{63} \mathrm{Bu}$ sırada Naphta ve Settembrini’ye ne olduğunu merak edenler için söyleyelim. Birbirlerine olan bitmez çıkışları, bir gün düello ile son buldu. Silahını ilk çeken kazanacaktı. Settembrini öldürme arzusundan uzak olduğu için silahı bilerek boş aldı. Birbirlerinden uzaklaşarak saymaya başladılar. Settembrini düşünceleri uğruna öldürmeyi değil ölmeyi göze almıştı. "Öldürmeyeceğim dostum, yapmayacağım. Kendimi onun kurşununa teslim edeceğim. Onurum bunu gerektiriyor.” ${ }^{64}$ Sayma bitince birbirlerini döndüler ve Naphta silahını çekerek kendi onuru uğruna namlusunu düelloyla ilgisi olmayan bir yöne çevirerek kendini başından vurdu. Ona ilk koşan, Settembrini oldu. Böylelikle intiharlara bir yenisi daha eklenmişti. Hans büyülü şarkılar uğruna ölmedi. Hiçbir şey eskisi gibi değildi artık. Soyut zaman onu gereğinden fazla değiştirmişti. Kendisine daha kıymetli olan başka bir şey buldu. Bir gün 34 numaralı odasını boşaltarak düzlüğe inmeye karar verdi, çünkü tutkusundan vazgeçmek yüreksizlikti. Sıradan olmasına rağmen yüreğindeki tutkuyu, kuzeni Joachim'in yarım kalan kahramanlık hayalini tamamlamak için orduya yazıldı. Thomas Mann, onun kahramanlık için bu gidişini Franz P. Schubert (1797-1828)' 1n Ihlamur Ă̆acı (Alm. Der Lindenbaum) (1827), bestesiyle aktarır. Geleceği parlak olmayan ve öykünün hatırı için anlatılan Hans'tan geriye şu sözler kalır;

\footnotetext{
60 A.g.e.s.359.

61 A.g.e.s.365.

62 A.g.e.s.377.

63 A.g.e.s.382.

64 A.g.e.s. 442.
} 


\section{"Bir ıhlamur ăgacı vardır orada}

\section{Tatl tatlı hayaller kurardim}

Gölgesinde uzanıp da

Kimi sevda sözleri kazımıștım, $O$ ă̆acı kabuğuna

Sevinçte de kederde de, Çekerdi beni hep yanına

Dalları uğuldar, usulca fisıldar

\section{Sesleniyorlardi sanki bana...}

\section{Yamacıma gel, dostum, Burada bulursun huzuru!'65}

"Uğurlar olsun sana Hans Castorp, yaşamın sadık ama sorunlu çocuğu. Öykün sona erdi. [...] Yaşasan da, olduğun yerde kalsan da - hoşça kal Hans! Geleceğin pek parlak sayılmaz. Yakalandığın kötülük dolu dans daha birçok günah dolu yıl sürecek ve biz senin bu işten sağ çıkacağına bahse giremeyiz. [...] Geçirdiğin ruhsal ve bedensel deneyimler sıradanlığını yüceltti ve bedeninin dayanamayacağına ruhunun dayanamasını sağladı. [...] Bu cinsel bedenden ve ölümden bir aşk düşünün doğabileceğini sezinlediğin anlar oldu. Dünyadaki bu ölüm şenliğinden ve bu yağmurlu akşam gökyüzünü, kızgın alevlere boğan, bu çirkin ateşten de günün birinde sevgi doğar $\mathrm{m} 1$ dersin?" 66

Sonuç olarak, Büyülü Dăg yapıtı bize modern düşünce içerisinde reddedemeyerek karşılaştığımız, zihnin onları tartışmaktan geri durmadığı, üzerine kesin belirlenimler yapamamış olsa dahi sorgulamaktan daima vazgeçmeyen sıradan bir kahramanla baş başa bırakmıştır. Yaşamın sorunlu çocuğu Hans, yaşam ve ölüm karşıtlığını sunmanın başarısıyla savaşta görülür. Yaşama tutunmak, yaşama değer katmak beden ve ruh sağllğı yerinde olan insanlar için geçerli olacakken, umutsuzluk, can sıkıntısı, sıradanlık, lekeler beraberinde ölümün getirdiği deneyimleri ölmeden de yaşatabilmiştir. Bu karşıtlı̆̆ın yanında yapıt bize düzlüğe ait olan somut zaman ve yukarıların soyut zaman anlayışını da sunmaktadır. Hans'ın hiçbir zaman zihninden atamadığı bu karşıtlık onu tanımlamaktan, belirlemekten de alıkoymaktadır. Zamanı mekânla ilişki bağlamında açıklamak Hans içinde biraz olsun iç rahatlatıcı olmuştur. İnsanın ruh ve beden ikiliği içinde zaman ve mekân bütünlügüüne oturması onun yalnızca tutarlı ve yaşama sadık olunabildiğini göstermektedir. Ayrıca Thomas Mann, zihin veya bedene düşkünlüğü onursuzluk olarak tanımlamaktadır. Sadece bedene tutkulu olan Naphta veya Joachim'in sonu ölümle sonuçlanırken zihne sıkıca bağlı olan Settembrini de Hans tarafından arkadaşlığı romanın sonunda terk edilir. Hans ise bu ikiliği kendinde barından genç bir kahramandır. Cevaplayamasa dahi sürekli kendiyle bir şeyleri sorup tartışıyor olması zihnine ve bir kadına veya müziğe âşık

65 Aslı Uluşahin, "206 Odal Sessizlik ve Iblamur Ağacı", 15.10.2018, https://www.kulturservisi.com/ p/206-odali-sessizlik-ve-ihlamur-agaci/, (26.11.2018).

66 s.458. Thomas Mann, (2013) Büyü̈lü Dă̆ (Cilt 2), çev. İris Kantemir, İstanbul: Can Yayınları. 
olması bedenine düşkünlüğü ile ilişkilendirilebilir. Karşıtların yazarı Thomas Mann roman boyunca soyut ve somut zaman, beden ve zihin, yaşam ve ölüm, sağlık ve hastalık, monist ve kozmopolit gibi pek çok temayı modernist özellikleri bağlamında önümüze sermiş oldu.

\section{Kaynaklar}

Mann, Thomas, (2013) Büyyülü Dăg (2 Cilt), çev. İris Kantemir, İstanbul: Can Yayınları.

Uluşahin, Asl1, "206 Odalı Sessizlik ve Iblamur Ağaci”, 15.10.2018, https://www.kulturservisi.com/p/206odali-sessizlik-ve-ihlamur-agaci/, (26.11.2018). 